\title{
AS RECENTES ALTERAÇÕES DO DEC.-LEI 911/69 E A PRISÃO CIVIL NA ALIENAÇÃO FIDUCIÁRIA EM GARANTIA — LEI 10.931/04
}

\author{
JOÃO AGNALDO DONIZETI GANDINI* \\ GlauCo POLACHINI GONÇALVES**
}

1. Introdução - 2. Breves noções sobre o contrato de alienação fiduciária - 3. Principais aspectos processuais da ação de busca e apreensão, sobretudo após o advento da Lei 10.931/04 - 4. A ação de depósito - 4.1. Conseqüências advindas da ação de depósito - 5 . A prisão civil na alienação fiduciária - 6. A influência do Pacto de San José da Costa Rica nas normas definidoras dos direitos e garantias fundamentais, bem como na questão da prisão civil na alienação fiduciária - 7. Considerações finais - 8. Bibliografia.

\section{Introdução}

O presente trabalho tem por finalidade, além de tecer comentários sobre as alterações dos parágrafos do art. $3^{\circ}$ do Dec.-Lei $911 / 69$, trazidas pela Lei 10.931/04, demonstrar a impossibilidade de ser decretada a prisão civil do devedor-fiduciante quando convertida a ação de busca e apreensão em depósito.

No que diz respeito às alterações dos parágrafos do art. $3^{\circ}$ do Dec.-Lei $911 / 69$, temos que, em algumas delas, o texto ficou impreciso e, portanto, é necessário buscarmos esclarecimentos para evitar que omissões possibilitem interpretações desencontradas e prejudiciais ao efetivo andamento da ação.

Já em relação à prisão civil na alienação fiduciária, a questão é muito mais complexa, necessitando de um estudo mais aprofundado, iniciando-se com a distinção da figura contratual referente ao contrato de depósito e o da alienação fiduciária.

* Mestre em Direito pela Unesp. Professor dos programas de graduação e pós-graduação da Faculdade de Direito da Universidade de Ribeirão Preto - Unaerp. Juiz de Direito em Ribeirão Preto-SP.

** Pós-graduando em Direito Processual Civil pela universidade de Ribeirão Preto - Unaerp. Advogado em Ribeirāo Preto-SP.

R. Dir. Adm.,

Rio de Janeiro, 238: 131-146, Out./Dez. 2004 
Sobre tal aspecto, o que mais se discute é a equiparação da figura do devedorfiduciante à do depositário. Porém, existe grande distinção entre ambos, motivo pelo qual dedicamos a maior parte do presente trabalho para definirmos os dois institutos, possibilitando, assim, a interpretação dos mesmos e sua aplicação no caso concreto.

O que se tem é que o devedor-fiduciante não pode ser equiparado ao depositário infiel, mesmo porque no contrato de alienação fiduciária não há o depósito do bem, mas sim, aquele a este é vinculado a título de garantia. Já no contrato de depósito, regulado pelo Código Civil, o bem é entregue ao depositário com o encargo de guarda, devendo ser restituído quando solicitado.

A prisão civil do devedor-fiduciante é tema bastante controvertido. Contudo, após concluídos os estudos realizados para a confecção do presente trabalho, outra conclusão não há senão a da impossibilidade de ser decretada a prisão civil do devedor-fiduciante inadimplente, requerida na ação de depósito.

O primeiro ponto analisado foi o da distinção, como já mencionado, entre o contrato de alienação fiduciária e o de depósito, este último regulado pelo Código Civil. Em seguida, analisou-se a questão da interpretação do texto constitucional, notadamente no que diz respeito ao inc. LVXII do art $5^{\circ}$, que trata das hipóteses autorizadoras da prisão civil por dívida.

Por derradeiro, trouxemos à pauta a questão da recepção, pelo Brasil, das normas instituídas pela convenção americana de direitos humanos, o "Pacto de San José da Costa Rica", cujo texto, após ratificado, teve aplicação imediata.

Todas as hipóteses estudadas nos levaram à conclusão de que a prisão civil do devedor-fiduciante, quando requerida na ação de depósito, é ilegal, tendo, inclusive, o Superior Tribunal de Justiça (STJ) pacificado a questão. Além do STJ, o Primeiro Tribunal de Alçada Civil de São Paulo ( $\left.1^{\circ} \mathrm{TACiv} / \mathrm{SP}\right)$ também vem firmando entendimento nesse sentido.

\section{Breves noções sobre o contrato de alienação fiduciária}

A alienação fiduciária foi instituída no Direito brasileiro para amparar o crédito das vendas de bens móveis, instituto que passou a ser usado, em larga escala, principalmente nas vendas de veículos automotores.

Anteriormente a essa introdução legislativa, a alienação fiduciária em garantia foi bastante usada em negócios simulados. Porém, somente com o advento da Lei $\mathrm{n}^{\circ} 4.728$, de 14 de julho de 1965 - que disciplinou o mercado de capitais - foi regulada, legislativamente, a alienação fiduciária em garantia, a ela sendo dedicado o art. 66 daquele diploma legal.

Contudo, a maneira imprecisa com que foi lançado o instituto de certo modo impedia a sua utilização em escala apreciável. Por tal razão, procurando sanar suas várias imperfeições, notadamente na parte processual, houve por bem o Governo modificá-lo, dando-lhe nova redação, ampliando e estabelecendo normas processuais $^{1}$, o que foi feito pelo Dec.-Lei $n^{\circ} 911$, de $1^{\circ}$ de outubro de 1969. 
O negócio fiduciário é muito utilizado na hipótese de uma instituição financeira, devidamente autorizada, pretender assegurar ao consumidor a possibilidade de aquisição de um bem sem lhe transferir de pronto o patrimônio.

Como somente transmite quem tem, explica-se porque nas vendas de bens figura como adquirente o consumidor, ou seja, aquele que é destinatário do financiamento direto. A venda mercantil é feita à vista, mediante intervenção da financeira que paga, em nome do credor, o valor da compra ao vendedor, que, por sua vez, se exclui da relação típica que nasce entre usuário e financiador.

A respeito, ensina Paulo Restiffe Neto:

“[...] há uma compra e venda entre o vendedor e o consumidor e a seguir uma transmissão de caráter peculiar, com fim de segurança, entre o financiado (devedor-fiduciante) e ofinanciador (credor-fiduciário). Neste segundo momento, quando surge o financiamento, é que se depara com o negócio jurídico denominado alienação fiduciária em garantia, que tem sua causa no negócio subjacente, de natureza civil ou mercantil" 2 .

Assim, a pessoa que recebe o financiamento e aliena o bem em garantia recebe o nome de alienante ou fiduciante e o credor ou financiador que adquire o bem em garantia é chamado de fiduciário.

A alienação fiduciária consiste na transferência feita, pelo devedor ao credor, da propriedade resolúvel e da posse indireta de um bem como garantia do seu débito, resolvendo-se o direito do adquirente com o pagamento da dívida garantida. Trata-se, portanto, de um negócio uno, embora composto de duas relações jurídicas, uma obrigacional, que se expressa no débito contratado, e outra real, representada pela garantia, que é um ato de alienação temporária ou transitória, uma vez que o fiduciário recebe o bem não para tê-lo como próprio, mas com o fim de restituí-lo com o pagamento da dívida ${ }^{3}$.

Na mesma linha de raciocínio, Fran Martins preceitua que a alienação fiduciária em garantia consiste "na operação em que, recebendo alguém financiamento para aquisição de bem móvel durável, aliena esse bem ao financiador, em garantia do pagamento de dívida contraída" 4 .

Por assim dizer, temos que a característica do contrato de alienação fiduciária é o fato de, ao fiduciário, serem transferidos o domínio resolúvel e a posse indireta da coisa móvel alienada independentemente da tradição efetiva do bem.

A coisa móvel alienada ficará em poder do devedor, que passa a ser o possuidor direto do bem, com todas as responsabilidades e todos os encargos que lhe incumbem, de acordo com a lei.

1 MARTINS, Fran. Contratos e obrigaçōes comerciais. 14. ed. Rio de Janeiro: Forense, 1996.

2 RESTIFFE NETTO, Paulo. Garantia fiduciária, 2. ed. São Paulo: Revista dos Tribunais, 1.076, pág. 91.

3 BUZAID, Alfredo. Alienação fiduciária em garantia, in Enciclopédia. p. 76, apud DINIZ, Maria Helena. Tratado teórico e prático dos contratos, 5. vol., São Paulo; Saraiva, 1993, p. 58.

4 Idem., p. 182 


\section{Principais aspectos processuais da ação de busca e apreensão}

Quando existe uma infração das obrigações avençadas por parte do devedor, isto é, se ele deixa de cumprir sua obrigação pelo modo e tempo devidos, de maneira culposa, deverá ser constituído em mora, que é requisito essencial para a propositura da ação de busca e apreensão.

A ação especial de busca e apreensão é o principal remédio processual e de aplicação mais geral à alienação fiduciária como instrumento hábil de pronta recuperação do objeto da garantia por parte do credor $^{5}$.

O Dec.-Lei $n^{\circ} 911$ deu à ação de busca e apreensão características de uma ação autônoma e não acessória e sujeita a regras especiais.

O sujeito ativo da ação de busca e apreensão é a pessoa que figurar, originariamente, no contrato de alienação fiduciária como financiador, posição reservada às instituições financeiras legalmente autorizadas a operar no mercado de capitais e registradas no Banco Central, ou, ainda, o avalista, fiador ou terceiro que tenha liquidado toda a dívida perante o credor, tomando o lugar deste, por sub-rogação no crédito e na garantia constituída pela alienação fiduciária, sendo que o sujeito passivo será o alienante devedor.

A ação de busca e apreensão não se reveste do caráter de medida preventiva preparatória, porque tem duplo efeito, ou seja, fim em si mesmo e meio. A lei declara, taxativamente, sua autonomia e independência em relação a qualquer outro procedimento, não só posterior, como anterior, sendo um processo autônomo e exaustivo (cognição parcial no plano horizontal e exauriente no vertical), cuja decisão põe fim ao litígio, autorizando a venda extrajudicial do bem ${ }^{6}$.

Ocorrendo a mora quanto à obrigação contratada pelo fiduciante, pelo simples vencimento do prazo para pagamento, o qual será comprovado por carta registrada expedida por Cartório de Títulos e Documentos ou pelo protesto do título, poderá o credor fiduciário requerer, judicialmente, a busca e apreensão do bem dado como garantia pelo devedor-fiduciante, sendo que esta ação, prevista no art $3^{\circ}$ do Dec.-Lei $911 / 69$, restringe-se à recuperação da coisa dada em garantia.

“Art. $3^{\circ}$. O proprietário fiduciário ou credor poderá requerer contra o devedor ou terceiro a busca e apreensão do bem alienado fiduciariamente, a qual será concedida liminarmente, desde que comprovada a mora ou o inadimplemento do devedor".

A petição inicial que requerer a busca e apreensão do bem dado em garantia deve conter os requisitos elencados nos incisos do art. 282 do Código de Processo Civil, a qual será deferida, liminamiente, desde que instruída com o instrumento do contrato e comprovada a mora do devedor.

5 Idem, p. 356.

6 idem, p. 357. 
Pela nova redação dos parágrafos do artigo $3^{\circ}$ do Dec.-Lei $911 / 69$, dada pela Lei $10.931 / 04$, concedida a liminar e executada a medida com a apreensão do bem alienado, o credor-fiduciário, após cinco dias da efetivação do ato, passará a ter a posse plena e exclusiva do bem independentemente de qualquer decisão judicial, podendo, inclusive, proceder aos atos de venda a terceiro, aplicando o preço no pagamento de seu crédito e das despesas decorrentes da cobrança, entregando ao devedor o saldo que houver.

Confira-se:

" $\$ 1{ }^{\circ}$ Cinco dias após executada a liminar mencionada no caput, consolidar-se-ão a propriedade e a posse plena e exclusiva do bem no patrimônio do credor fiduciário, cabendo às repartiçōes competentes, quando for o caso, expedir novo certificado de registro de propriedade em nome do credor, ou de terceiro por ele indicado, livre do ônus da propriedade fiduciária."

Pode o devedor-fiduciante, no prazo de 05 (cinco) dias, contados da data da efetivação da busca e apreensão, pagar a dívida integral do débito inadimplido, tendo, por consequiência, a restituição do bem livre de qualquer ônus.

É o que preceitua o $\S 2^{\circ}$ do art. $3^{\circ}$ :

"No prazo ao $\$ 1^{\circ}$, o devedor fiduciante poderá pagar a integralidade da divida pendente, segundo os valores apresentados pelo credor fiduciário na inicial, hipótese na qual o bem lhe será restituído livre do ônus."

Optando, ou não, pelo pagamento integral da dívida, poderá o devedor-fiduciante, no prazo de 15 (quinze) dias, também contado da data da execução da medida, apresentar contestação:

" $\$ 3^{\circ} \mathrm{O}$ devedor fiduciante apresentará resposta no prazo de quinze dias da execução da liminar".

“ $\S 4^{\circ}$ A resposta poderá ser apresentada ainda que o devedor tenha se utilizado da faculdade do $\S 2^{\circ}$, caso entenda ter havido pagamento a maior $e$ desejar restituição".

No que diz respeito à contestação, a redação anterior restringia as hipóteses de defesa do réu, possibilitando-lhe apenas as alegações de "pagamento do débito vencido ou o cumprimento das obrigações contratuais" $\left(\S 2^{\circ} \text {, art. } 3^{\circ}\right)^{7}$. Sobre tal aspecto havia grande discussão, principalmente pela ofensa aos princípios constitucionais da igualdade, da ampla defesa e do contraditório (art. $5^{\circ}$, inc. LV) ${ }^{8}$, embora predominasse o entendimento de que tal norma havia sido recepcionada pela CF/88.

7 "Na contestação só se poderá alegar o pagamento do débito vencido ou o cumprimento das obrigações contratuais."

8 "aos litigantes, em processo judicial ou administrativo, e aos acusados em geral são assegurados o contraditório e a ampla defesa, com os meios e recursos a ela inerentes" 
Pelo texto atual, diga-se, de forma acertada, o legislador silenciou sobre referidas restrições, dando margem para que o réu, como de direito, possa, quando da contestação, alegar todos os fatos que entender necessários para defender-se.

Outro ponto a ser observado é que o texto, em momento algum, se refere à citação do réu. Preceitua o art. 213 do Código de Processo Civil que a "citação é o ato pelo qual se chama a juízo o réu ou o interessado a fim de se defender". E, complementando, o art. 214, do mesmo diploma legal, estabelece que "para a validade do processo, é indispensável a citação inicial do réu".

Percebe-se que o legislador, ao omitir a necessidade de se proceder à efetiva citação do réu, deixa o texto impreciso, dando azo, assim, para se criar confusão na sua interpretação.

Então, objetivando sanar a imprecisão com que o texto tratou do tema - na realidade, foi omisso - , a seguir, buscaremos solucionar a questão.

É certo que, defenda a liminar e concedida a busca e apreensão do bem alienado, o juiz, necessariamente, determinará que, executada a medida, seja feita a citação do réu.

A primeira hipótese a ser observada é a de que, executada a medida, tendo sido o bem encontrado na posse do réu, ato contínuo será realizada sua citação para que, no prazo de 15 (quinze) dias - e não mais três, como na redação anterior -, apresente resposta. Ambos os atos (execução da medida e citação) terão ocorrido na mesma data.

Referida hipótese não possibilita qualquer interpretação distinta quanto ao termo inicial para a contagem do prazo, mesmo porque a citação do réu foi realizada, como mencionado, ato contínuo da execução da medida. Ou seja, o bem estava na posse do devedor-fiduciante, que tomou conhecimento da apreensão, e, com a citação, de que o prazo para a apresentação da resposta é de 15 (quinze) dias, contados da execução da medida (cuja data coincide com a da citação).

Veja-se agora a hipótese de, executada a medida, e, quer porque o réu não esteja na posse do bem, quer porque não esteja presente no ato da apreensão, não ser o mesmo citado. Independentemente de o autor já poder dar cumprimento ao quanto estabelecido no $\S 1^{\circ}$ do art. $3^{\circ}$, o prazo do $\S 2^{\circ}$, bem como o do $\S 3^{\circ}$, começará a fluir da data da juntada aos autos do mandado de citação, devidamente cumprido?

$\mathrm{O}$ que se percebe é que, não raro, acontece de o devedor-fiduciante não estar na posse do bem quando da sua apreensão. Por vezes, o devedor-fiduciante reside na comarca onde é demandado, mas, após diligências, constata-se que o bem se encontra com terceira pessoa que reside em comarca distinta. Expedida a carta precatória, é o bem apreendido. Contudo, resta a diligência de citação do réu, que se dará na comarca deprecante. Assim, os prazos mencionados nos $\S \S 2^{\circ}$ e $3^{\circ}$ começarão a fluir somente da data da juntada aos autos do mandado de citação, devidamente cumprido e não da execução da medida, ocorrida antes e sem que o réu tenha ciência da ação. 
Logo, tanto o prazo para defesa quanto para o pagamento do valor cobrado pelo credor deve ser contado da citação - ato de ciência - e não da execução da medida como, de forma imprecisa, sugere o texto atual.

A norma anterior condicionava a citação do réu à prévia apreensão do bem, o que não ocorre com a redação atual. Todavia, a citação é ato imprescindível do processo e deve, de regra, ser realizada após a apreensão do bem, dado que o réu, antes desta medida, se tomar conhecimento da ação, poderá causar embaraços à sua execução.

Quando negativa a diligência de busca e apreensão, não se instaura a instância, mesmo porque não houve citação válida, podendo o credor, nos mesmos autos, recorrer à ação executiva, na qual serão penhorados bens do devedor, tantos quantos forem necessários para o pagamento de seu débito, ou, ainda, requerer a conversão da ação de busca e apreensão em ação de depósito.

A sentença que julgar a ação é passível de recurso de apelação, que será recebido apenas no seu efeito devolutivo (art. $3^{\circ}, \S 5^{\circ}$ ).

Uma vez julgado improcedente o pedido do autor, o legislador, com o objetivo de amenizar os prejuízos suportados pelo devedor-fiduciante com a venda antecipada do bem por parte do credor-fiduciário, previu a condenação deste ao pagamento de multa equivalente a $50 \%$ (cinqüenta por cento) ao valor financiado. Importante frisarmos que referida condenação somente será aplicada no caso de o bem já ter sido alienado pelo credor-fiduciário. É o que determina o $\S 6^{\circ}$ do art. $3^{\circ}$ do Dec.-Lei 911/69:

“§ $6^{\circ} \mathrm{Na}$ sentença que decretar a improcedência da ação de busca e apreensão, o juiz condenará o credor fiduciário ao pagamento de multa, em favor do devedor fiduciante, equivalente a cinqüenta por cento do valor originalmente financiado, devidamente atualizado, caso o bem já tenha sido alienado".

\section{A ação de depósito}

Para não nos distanciarmos do foco principal do tema abordado, deixaremos de adentrar nos aspectos da ação executiva, passando, desde já, às peculiaridades atinentes e relevantes da ação de depósito que dá origem à questão da prisão civil na alienação fiduciária.

O negócio da alienação fiduciária cria uma relação jurídica entre o fiduciante e o fiduciário caracterizada pela confiança que tem o primeiro de - sendo o dono da coisa - aliená-la ao segundo.

Assim, caso o bem alienado não seja encontrado ou não se ache em poder do fiduciante por ocasião da busca, o fiduciário poderá requerer a conversão do pedido de busca e apreensão, nos mesmos autos, em ação de depósito, obedecido, então, o estabelecido no art. $4^{\circ}$ do Dec.-Lei $911 / 69$. 
"Art. $4^{\circ}$. Se o bem alienado fiduciariamente não for encontrado ou não se achar na posse do devedor, o credor poderá requerer a conversão do pedido de busca e apreensão, nos mesmos autos, em ação de depósito, na forma prevista no Capítulo II, do Título I, do Livro IV. do Código de Processo Civil."

Assim, no caso de mora ou inadimplemento, exige o credor, por meio da ação de busca e apreensão, a entrega do bem, mas, se este não é encontrado ou não se achar na posse do devedor, poderá, o credor, requerer a conversão daquela em ação de depósito.

A ação de depósito é cabível, exclusivamente, contra o devedor-fiduciante, mesmo porque é quem tem a posse direta do bem.

É certo que, tratando-se de ação de depósito, esta somente pode ser aplicada mediante a ocorrência de duas hipóteses: a) se o bem alienado fiduciariamente não for encontrado, ou b) se não se achar na posse do devedor.

Portanto, apenas a ocultação dolosa do bem ou a sua disposição fraudulenta, impeditiva da sua localização e apreensão, expõem o devedor inadimplente à compulsão específica da ação de depósito ${ }^{10}$. É de se frisar que não pode ser eleita esta via judicial sem que seja precedida da busca e apreensão para efetiva comprovação da alegada infidelidade depositária.

No caso da ação de depósito, fica-se no plano da perseguição do bem, sendo que, se este for localizado, poderá o credor fiduciário, a qualquer momento, requerer a busca e apreensão, mesmo após o oferecimento de contestação por parte do devedor, bem como se já tiver sido prolatada a sentença.

\subsection{Conseqüências advindas da ação de depósito}

Deferida a conversão da ação de busca e apreensão em ação de depósito, o réu será citado para, no prazo de vinte e quatro horas, entregar o bem ou consignar o equivalente em dinheiro. No caso de, após a citação, permanecer o réu inerte, o juiz julgará antecipadamente o feito, prolatando a sentença e determinando a expedição do mandado para entrega do bem.

Ocorrendo a citação do réu e se este somente contestar, o juiz saneará o processo e determinará a produção de provas, sentenciando a seguir. Se o pedido for julgado procedente, ordenará o juiz a expedição de mandado de entrega do bem, em 24 (vinte e quatro) horas, ou do equivalente em dinheiro, sob pena de prisão. $O$ mesmo ocorre, como já referido anteriormente, quando o réu, citado, permanecer inerte.

Muito se discute sobre a possibilidade e constitucionalidade da prisão civil do depositário infiel nos casos de alienação fiduciária e, para retomarmos tal discussão,, necessário se faz, inicialmente, tecermos alguns comentários sobre a expressão "depositário infiel". 
O inciso LVXII do art. $5^{\circ}$ da Constituição Federal é taxativo ao expressar que "não haverá prisão civil por dívida, salvo a do responsável pelo inadimplemento voluntário e inescusável de obrigação alimentícia e a do depositário infiel".

Interpretando-se referido inciso, deve-se entender que somente estão sujeitos à prisão civil o devedor de alimentos e o depositário infiel.

Quanto à prisão civil do devedor de alimentos, temos que não há o que se discutir quanto à sua possibilidade. Contudo, quanto ao depositário infiel, necessário se torna um estudo mais aprofundado sobre o tema, principalmente em relação à distinção do instituto do depósito previsto no Código Civil (contrato de depósito) e o tratado na alienação fiduciária em garantia.

O contrato de alienação fiduciária em garantia não pode ser comparado com o contrato de depósito a que se refere o Código Civil porque, neste, uma pessoa recebe um bem alheio com a obrigação de guardá-lo e restitui-lo quando exigido e, naquele, o bem se transforma em mera garantia.

A condição necessária para que alguém seja considerado depositário é a formalização de um contrato de depósito nos termos do que preceitua o Código Civil, o que não ocorre no contrato de alienação fiduciária.

O devedor-fiduciante não pode ser considerado depositário, mesmo porque "em nenhum momento a ele se atribui o bem para exercício do dever de custódia estruturado na sua guarda e conservação, muito menos para o exercício de um dever de restituição quando exigido pelo credor fiduciário" "1.

Orlando Gomes segue a mesma linha de raciocínio, dizendo que "o devedorfiduciante não é, a rigor, depositário, pois não recebe a coisa para guardar, nem o credor-fiduciário a entrega para esse fim, reclamando-a quando não mais lhe interesse a custódia alheia" 12 .

Por assim dizer, conclui-se que inexiste o depósito na alienação fiduciária, isso porque o devedor não deve devolver o bem a ele entregue, permanecendo com ele até o pagamento integral do financiamento que deu origem à sua aquisição.

Valério de Oliveira Mazzuoli ensina que:

"Não resta dúvida que o devedor-fiduciante não é depositário. A ele não se atribui o dever de custódia do bem, muito menos o dever de restitui-lo quando exigido. Ao depositário a coisa é dada com a obrigação formal de devolvê-la, obrigação esta, que inexiste no caso da alienação fiduciária que se constitui mera garantia de mútuo. Além disso, é ainda de considerar-se que na alienação fiduciária não existe, efetivamente, a confiança que o depositante deposita no depositário de um contrato genuíno de depósito, de modo que o devedor-fiduciante jamais pode ser, por esse motivo, conside-

11 RODRIGUES ALVES, Vilson. Responsabilidade civil dos estabelecimentos bancários, 1. ed., $2^{\mathbf{a}}$ tiragem. Campinas: Brookseller Editora, 1997, p. 256.

12 GOMES, Oriando. Alienação fiduciária em garantia, 4. ed. São Paulo: Editora Revista dos Tribunais, 1975, p. 130. 
rado infiel em caso de descumprimento do contrato. Onde não há confiança não há infidelidade" ${ }^{13}$.

Não havendo contrato de depósito, impossível equiparar o devedor-fiduciante ao depositário, mesmo porque, firmado o contrato de alienação, o devedor passa a exercer a condição de proprietário do bem alienado, ainda que tal propriedade esteja pendente de cláusula resolutiva.

"Depósito é depósito, garantia de dívida é garantia de dívida. Não.se confunde, pois, o inconfundível" 14 .

A alienação fiduciária não é depósito, não podendo, portanto, ser o devedor-fiduciante equiparado a depositário e, muito menos, não cumprida sua obrigação, a depositário infiel. $O$ depósito não se presume.

Preceitua o art. 627 do Código Civil: "Pelo contrato de depósito recebe o depositário um objeto móvel, para guardar, até que o depositante o reclame". Portanto, somente pode ser considerado depositário infiel aquele que recebe um bem para guardá-lo, e, quando solicitada a sua restituição, não o faz.

Quando a Constituição se refere ao depositário infiel (art. $5^{\circ}$, LXVII) está tratando do sujeito passivo da relação obrigacional chamada contrato de depósito (Cód. Civil), e não da figura anômala, referida no Decreto-lei $n^{\circ} 911 / 69^{15}$. Portanto, afastada fica, a nosso ver, a aplicação do termo "depositário infiel" ao devedor-fiduciante.

\section{A prisão civil na alienação fiduciária}

Como se viu, a Constituição Federal autoriza a prisão civil apenas do depositário infiel, ou seja, daquele que recebe do proprietário um bem para guardar e se obriga a devolvê-lo quando o proprietário pedir a sua devolução, nos termos do art. 652 do Código Civil.

De outra sorte, o art. $5^{\circ}$, LXVII, da Constituição Federal não autoriza a prisão civil de quem não é depositário infiel. Isso quer dizer que somente está passível de prisão civil aquele que, mediante contrato de depósito, se tomou depositário e, pelo não cumprimento das obrigações, depositário infiel.

Depositário é aquele que guarda bem alheio, não se podendo, portanto, dizer que o devedor-fiduciante é depositário se é ele quem corre todo o risco da perda da coisa desde o início do negócio ${ }^{16}$. Ademais, a finalidade do contrato de alienação fiduciária é a garantia e não a guarda do bem.

13 MAZZUOLI, Valerio de Oliveira, Prisão civil por divida e o Pacto de San José da Costa Rica. 1. ed, Rio de Janeiro: Editora Forense, p. 42.

14 Idem, ibidem.

15 Idem. ibidem.

16 AZEVEDO, Álvaro Villaça. Prisão civil por dívida. São Paulo: Editora Revista dos Tribunais, 1993, p. 109. 
Nem se alegue que a prisão civil do devedor-fiduciante é o único meio de coagi-lo a entregar o bem ou seu equivalente em dinheiro e que, com sua inviabilidade, impossível seria às instituições financeiras buscar a satisfação de seu crédito quando frustrada a busca e apreensão.

A questão é que nos termos do Dec.-Lei $911 / 69$ é lícito às instituições financeiras, quando frustrada a busca e apreensão, optar pela ação de execução, não restando, portanto, somente a hipótese da ação de depósito.

Além do mais, como já demonstrado acima, não há que se confundir a figura do depositário infiel com a do devedor-fiduciante, mesmo porque detêm características totalmente diferentes e bem definidas na lei.

O devedor-fiduciante não é depositário e, afastando qualquer possibilidade de interpretação distinta, note-se decisão do Superior Tribunal de Justiça (STJ), relatada pelo Ministro Vicente Leal:

"Segundo a ordem jurídica estabelecida pela Carta Magna de 1988, somente é admissivel prisão civil por dívida nas hipóteses de inadimplemento voluntário e inescusável de obrigação alimentícia e de depositário infiel $\left(C F\right.$, art. $\left.5^{\circ}, L X V I I\right) . O$ devedor-fiduciante que descumpre a obrigação pactuada e não entrega a coisa ao credor-fiduciário não se equipara ao depositário infiel, passível de prisão civil, pois o contrato de depósito, disciplinado nos arts. 1.265 a $1.287^{17}$, do Código Civil, não se equipara, em absoluto, ao contrato de alienação fiduciária. A regra do art. $1^{\circ}$ do Decreto Lei $n^{\circ} 911 / 69$, que equipara a alienação fiduciária em garantia ao contrato de depósito, perdeu a sua validade jurídica em face da nova ordem constitucional" ${ }^{18}$.

A esse respeito, ou seja, sobre a impossibilidade da prisão civil do devedor-fiduciário, o STJ vem se fumando nessa orientação:

“A jurisprudência da $6^{a}$ Turma ao STJ orienta-se no sentido de que, na alienação fiduciária, torna-se incabivel a prisão civil do devedor-fiduciante, por não estar o mesmo equiparado a depositário, Recurso Provido" ${ }^{19}$.

Como se vê, a $6^{\text {a }}$ turma do STJ uniformizou jurisprudência sobre o tema, não permitindo a prisão civil do devedor-fiduciante.

O mesmo entendimento está sendo esposado pelo Primeiro Tribunal de Alçada Civil de São Paulo (1 $\left.1^{\circ} \mathrm{TACiv} / \mathrm{SP}\right)$ :

17 A título de esclarecimento, o contrato de depósito, com o advento do novo Código Civil, é regulado pelos arts. 627 a 652, e não mais pelos arts. 1.265 a 1.287 , como referido no texto.

18 HC 3.206-SP, 6* Turma ao STJ, por maioria, DJ 05.06.95, p. 16.686

19 HC 4.319-GO, 6* Turma do STJ, DJ 21.08.95. p. 25.408. 
"Alienação Fiduciária - Prisão do depositário - Não tendo por finalidade a guarda, mas a garantia, não na depósito, nem depositário infiel a justificar a prisão civil, que resulta em flagrante ilegalidade - A equiparação do fiduciante ao depositário deve ser banida do direito - 'Habeas Corpus' concedido". ${ }^{20}$

É mesmo de se perceber que o devedor-fiduciante não se equipara à figura do depositário. Isto porque o contrato de alienação fiduciária não tem, como finalidade, a guarda, mas, sim, a garantia. Não havendo depósito no contrato de alienação fiduciária, não existe a figura do "depositário infiel" quando não cumprida a obrigação contratual.

Com a não equiparação do devedor-fiduciante à figura do depositário infiel, o que impossibilita sua prisão quando não localizado o bem, temos que, além de tal conclusão, é importante ressaltarmos que o inciso LVXII do art $5^{\circ}$ da Constituição Federal há de ser interpretado de forma restritiva e não ampliativa.

Referido texto constitucional é taxativo e restringe a possibilidade de prisão civil apenas para as hipóteses do responsável pelo inadimplemento voluntário e inescusável de obrigação alimentícia e a do depositário infiel.

Claro já ficou, pelo quanto exposto acima, que o devedor-fiduciante, notadamente pela distinção das figuras contratuais, não se equipara ao depositário infiel. Já por tal aspecto, a Constituição, interpretada de forma restritiva - diga-se, que é a correta - afasta a possibilidade de ser decretada a prisão do devedor-fiduciante.

Seguindo a lição de Konrad Hesse:

[...] " a interpretação tem significado decisivo para a consolidação e preservação normativa da Constituição. A interpretação constitucional está submetida ao princípio da ótima concretização da norma. A interpretação adequada é aquela que consegue concretizar, de forma excelente, o sentido da proposição normativa dentro das condições reais dominantes numa determinada situação [...]. A dinâmica existente na interpretação construtiva constitui condição fundamental da força normativa da Constituição e. por conseguinte, de sua estabilidade. Caso ela venha a faltar, tornar-se-á inevitável, cedo ou tarde, a ruptura da situação jurídica vigente" ${ }^{21}$.

Não há qualquer previsão no texto constitucional, nem mesmo em qualquer outro diploma legal, autorizadora da prisão do devedor-fiduciante e, com a interpretação restritiva do texto constitucional, o que se demonstra ser o correto, não resta margem para amparar a restrição da liberdade nos casos de alienação fiduciária.

20 HC 546.443-7/00, $3^{a}$ Câm. unânime, rel. Juiz Aloísio Toledo, DJ 18.05.93, Boletim 57 JTA-LEX $143 / 190$.

21 HESSE, Konrad. A força normativa da Constituiçāo (die normative Kraft der Verfassong), Trad. Gilmar Ferreira Mendes. Porto Alegre: Sérgio Antônio Fabris Editor, 1991, pp. 22/23. 
6. A influência do pacto de san josé da costa rica nas normas definidoras dos direitos e garantias fundamentais, bem como na prisão civil na alienação fiduciária

Não resta dúvida sobre a forte influência sofrida pela Constituição Federal quando ratificados pelo Brasil os tratados internacionais sobre direitos humanos, em especial a convenção americana de direitos humanos, conhecida como "Pacto de San José da Costa Rica".

Inicialmente, importante esclarecermos que os tratados de direitos humanos têm incorporação automática no ordenamento constitucional brasileiro. É o que estatui $o \S 1^{\circ}$ do art $5^{\circ}$ da Constituição Federal:

"As normas definidoras dos direitos e garantias fundamentais têm aplicação imediata".

Note-se que nossa Constituição concede aplicação imediata a todos os direitos e garantias fundamentais, inclusive os provenientes de tratados, "vinculando-se todo o judiciado nacional a esta aplicação, e obrigando, por conseguinte, também o legislador, aí incluído o legislador constitucional" 22 .

Não pretendemos, aqui, tratar, a fundo, da questão da recepção dos tratados à nossa Carta, mesmo porque o que se pretende é relacionar tal recepção com a aplicação dos direitos e garantias fundamentais, agora ampliados, à prisão civil do depositário infiel.

Para aqueles que ainda não se convenceram da impossibilidade de se decretar a prisão civil do devedor-fiduciante sob o aspecto da distinção dos institutos contratuais, bem como daquele da interpretação restritiva do texto constitucional, temos que mais um aspecto há que ser incluído e levado em consideração para a racionalização do tema.

A prisão civil, não se negue, é um meio coercitivo para que o devedor cumpra com sua obrigação. $O$ fato é que, para o devedor-fiduciante, a prisão civil, apesar de não visar à pena, mas sim à coerção, não deixa de ter, para aquele, o sabor de pena.

Com a prisão do devedor-fiduciante o que se busca é levar ao credor-fiduciário uma retribuição pelo prejuízo tomado. Isso significa dizer que, apesar de tal prisão não ter caráter penal, mas sim, coercitivo, a carga aflitiva suportada pelo devedorfiduciante será a mesma, ou maior, que a de um criminoso, e tal, principalmente nos dias atuais, não pode ocorrer.

O que temos é que, após a Constituição de 1988, não mais é possível coagir o devedor-fiduciante, mediante prisão, a pagar as prestações devidas.

O Pacto de San José Costa Rica, ao qual o Brasil aderiu sem reservas, estabelece, notadamente em seu art. $7^{\circ}, \S 7$, que:

22 BACHOF, Otto. Normas constitucionais inconstitucionais? Coimbra: Livraria Almedina, 1994, p. 33. 
"Ninguém deve ser detido por dívidas. Este princípio não limita os mandados de autoridade judiciária competente expedidos em virtude de inadimplemento de obrigação alimentar".

A interpretação que se dá ao citado texto é a de que somente as dívidas alimentícias podem ensejar a prisão civil.

Como se percebe, a figura do depositário infiel não consta do texto acima e, se assim é, além dos argumentos já alinhados, mais um há que ser lançado no rol para afastar, definitivamente, a possibilidade de ser decretada a prisão civil do devedorfiduciante.

Observe-se a lição de Mazzuoli:

"Se as normas definidoras dos direitos e garantias fundamentais têm aplicação imediata, os tratados internacionais de proteção dos direitos humanos, uma vez ratificados, por também conterem normas que dispõem sobre direitos e garantias fundamentais, terão, dentro do contexto constitucional brasileiro, idêntica aplicação imediata [...]. Atribuindo-lhes a Constituição a natureza de 'normas constitucionais', passam os tratados, pelo mandamento do citado $\S 1^{\circ}$ do seu art. $5^{\circ}$, a ter aplicabilidade imediata, dispensando-se, assim, a edição de decreto de execução para que irradiem seus efeitos tanto no plano interno como no plano internacional" ${ }^{23}$.

Fica claro que o tratado internacional de proteção dos direito humanos (Pacto de San José da Costa Rica), diga-se, uma vez ratificado, tem imediata aplicação no Brasil.

Por assim dizer, ao definir o texto do retendo tratado que somente o inadimplemento alimentar é passível de acarretar a prisão civil, excluída fica a figura do infiel depositário e, mais ainda, a do devedor-fiduciante que, como vastamente justificado, são figuras que não se confundem.

\section{Considerações finais}

1 - A alienação fiduciária consiste na transferência, feita pelo devedor ao credor, da propriedade resolúvel e da posse indireta de um bem como garantia do seu débito, resolvendo-se o direito do adquirente com o pagamento da dívida garantida. Trata-se, portanto, de um negócio uno, embora composto de duas relações jurídicas, uma obrigacional, que se expressa no débito contratado, e outra real, representada pela garantia, que é um ato de alienação temporária ou transitória, uma vez que o fiduciário recebe o bem não para tê-lo como próprio, mas com o fim de restituí-lo com o pagamento da dívida ${ }^{24}$.

23 MAZZUOLI, Valério de Oliveira. Op. cit., p. 134.

24 Idem. Ibidem. 
A ação de busca e apreensão, na alienação fiduciária, não se reveste do caráter de medida preventiva preparatória, porque tem duplo efeito, ou seja, fim em si mesmo e meio. A lei declara, taxativamente, sua autonomia e independência em relação a qualquer outro procedimento, não só posterior, como anterior, sendo um processo autônomo e exaustivo, cuja decisão põe fim ao litígio.

2 - As alterações sofridas pelo Dec.-Lei $911 / 69$, trazidas pela Lei 10.931 , de 08 de agosto de 2004, trouxeram consideráveis modificações processuais ao instituto. Da mesma forma, algumas imprecisões tiveram que ser esclarecidas, principalmente a que diz respeito à citação que, por omissão do legislador, acarretou dúvidas quanto à contagem do prazo para a apresentação de contestação.

a) A primeira alteração importante foi a de autorizar, após cinco dias da data da execução da medida (apreensão), que a posse plena e exclusiva do bem passe imediatamente ao credor-fiduciário, autorizando-o, inclusive, a proceder à venda do bem a terceiro, antes mesmo da sentença.

b) Pela nova redação dos parágrafos do art. $3^{\circ}, 0$ devedor-fiduciante poderá, também após cinco dias da execução da medida, efetuar o pagamento integral da dívida mencionada na inicial, recebendo o bem livre de quaisquer ônus.

c) O prazo para a apresentação da contestação foi alterado para 15 (quinze) dias, quando, pela redação anterior, o prazo era de 03 (três) dias. $O$ texto preceitua que a contestação deverá ser apresentada no prazo de 15 (quinze) dias, e o pagamento a que se refere o $\S 2^{\circ}$, no prazo de 05 (cinco) dias, ambos a contar da data da execução da liminar. Contudo, sendo a citação ato indispensável dentro do processo, temos que, independentemente da forma pela qual tenha sido a citação operada (mandado, precatória, correio etc.), o prazo começará a fluir sempre da data da juntada aos autos do documento comprobatório da citação. Assim, tendo sido o bem encontrado na posse do réu, ato contínuo será realizada sua citação para que, no prazo de 15 (quinze) dias, apresente resposta, mesmo porque ambos os atos (execução da medida e citação) terão ocorrido na mesma data. De outra sorte, executada a medida, e, quer porque o réu não está na posse do bem, quer porque não está presente no ato da apreensão, o prazo para a apresentação da contestação somente começará a fluir da data da juntada aos autos do mandado de citação, devidamente cumprido.

3 - O principal escopo do trabalho foi o de demonstrar que a prisão civil do devedor-fiduciante é ilegal. Por primeiro, foi feita a distinção da figura do depositário, regulada pelo contrato de depósito previsto no Código Civil e a do devedorfiduciante, regulada no contrato de alienação fiduciária.

Ficou demonstrado que o contrato de alienação fiduciária em garantia não pode ser comparado com o contrato de depósito a que se refere o Código Civil, isso porque, neste, uma pessoa recebe um bem alheio com a obrigação de guardá-lo e restituí-lo quando exigido e, naquele, o bem se transforma em mera garantia. A condição necessária para que alguém seja considerado depositário é a formalização de um contrato de depósito nos termos do que preceitua o Código Civil, o que não ocorre no contrato de alienação fiduciária. Pela distinção dos institutos, ficou demonstrado que o devedor-fiduciante não se equipara ao depositário e, por tal, sua prisão, quando não paga a dívida, é ilegal. 
4 - O inc. LVXII do art. $5^{\circ}$ da CF há que ser interpretado de forma restritiva, e não ampliativa. O texto constitucional é taxativo e restringe a possibilidade de prisão civil apenas para as hipóteses do responsável pelo inadimplemento voluntário e inescusável de obrigação alimentícia e a do depositário infiel. Pelo quanto estudado, ficou demonstrado que o devedor-fiduciante, notadamente pela distinção das figuras contratuais, não se equipara ao depositário infiel. Já por tal aspecto, a Constituição, interpretada de forma restritiva - diga-se, que é a correta - afasta a possibilidade de ser decretada a prisão do devedor-fiduciante.

5 - A forte influência sofrida pela Constituição Federal quando ratificados pelo Brasil os tratados internacionais sobre direitos humanos, em especial a convenção americana de direitos humanos, conhecida como "Pacto de San José da Costa Rica", nos trouxe outro parâmetro para nos apoiarmos a fim de, definitivamente, excluirmos a possibilidade da decretação da prisão civil por dívida nos casos de contratos de alienação fiduciária. Nossa Constituição concede aplicação imediata a todos os direitos e garantias fundamentais, inclusive os provenientes de tratados, vinculando todo o judiciário nacional a esta aplicação, e obrigando, por conseguinte, também o legislador, aí incluído o legislador constitucional. $\mathrm{O}$ art. $7^{\circ}, \S 7$, do "Pacto de San José da Costa Rica estabelece, com clareza, que "ninguém deve ser detido por dívidas. Este princípio não limita os mandados de autoridade judiciária competente expedidos em virtude de inadimplemento de obrigação alimentar". A interpretação que se dá ao citado texto é a de que somente as dívidas alimentícias podem ensejar a prisão civil, excluído que fica, assim, o depositário infiel e, principalmente, o devedor-fiduciante que, como estudado, são figuras distintas.

\section{Bibliografia.}

AZEVEDO, Álvaro Villaça. Prisão civil por divida. São Paulo: Editora Revista dos Tribunais, 1993.

BACHOF, Oito. Normas constitucionais inconstitucionais? Coimbra: Livraria Almedina, 1994.

BUZAID, Alfredo. Alienação fiduciária em garantia. 5. vol. São Paulo: Saraiva, 1993.

GOMES, Orlando. Alienação fiduciária em garantia, 4. ed. São Paulo: Editora Revista dos Tribunais, 1975.

HESSE, Konrad. A força normativa da Constituição (die normative Kraft der Verfassung). Trad. Gilmar Ferreira Mendes. Porto Alegre: Sérgio Antônio Fabris Editor, 1991.

MARTINS, Fran. Contratos e obrigações comerciais. 14. ed. Rio de Janeiro: Forense, 1996.

MAZZUOLI, Valério de Oliveira. Prisão civil por dívida e o Pacto de San José da Costa Rica. l. ed. Forense: Rio de Janeiro, 2002.

RESTIFFE NETTO, Paulo. Garantia fiduciária. 2. ed. São Paulo: Revista dos Tribunais, 1994.

RODRIGUES ALVES, Vilson. Responsabilidade civil dos estabelecimentos bancários, 1. ed., $2^{\text {a }}$ tiragem. Campinas: Brookseller Editora, 1997. 